\title{
Cytotoxic, Antioxidant, and Caspase-9 activity of 2-(3,5-dibromo-4- methoxyphenyl)3(3-mercapto-5(pyridine-4-Yl)4H1,2,4-triazol-4yl)-thiazolidine4- one against various human tumor cell lines
}

\author{
Firas A. Hassan \\ Department of Chemistry, College of Science, Al-Nahrain University, Baghdad-Iraq. \\ Corresponding Author: firas.hassan2014@yahoo.com
}

\begin{abstract}
Caspase, or cysteine-dependent aspartate-directed proteases, belong to a extremely protected group of cysteine proteases that have a crucial role within the numerous phases of apoptosis. The derivative of 2-(3,5-dibromo-4-methoxyphenyl)-3(3-mercapto-5(pyridine-4-yl)-4H1,2,4-triazol-4yl)-thiazolidine4-one (C3) described a high toxic efficacy in murine melanoma tumor(B16F10), human prostate tumor (LCCaP), and non-small cell lung tumor (H1299) by measured half maximal inhibitory concentration $\mathrm{IC}_{50}$ values were $41 \mu \mathrm{g} / \mathrm{ml}, 54.11 \mu \mathrm{g} / \mathrm{ml}$, and $109.9 \mu \mathrm{g} / \mathrm{ml}$, respectively, which was the most significant cytotoxic towards $(\mathrm{B} 16 \mathrm{~F} 10)$ cell line treated at $(\mathrm{P}<0.0001)$ for 24 hours. No significant cytotoxic effect were observed in human neuronal glioblastoma cell line (U138 MG) and testes cell lines (Tera-1) at P-value (0.650), by comparison with normal cell line. Furthermore, 1,2,4-Triazole derivative (C3) encouraged In-vitro increase in caspase-9 activity in (B16F10) tumor cell line. Derivative (C3) effect on the mechanism of apoptosis reveal a highly increased caspase- 9 activity, which observed at $10 \mu \mathrm{g} / \mathrm{ml}$ concentrate in $\mathrm{B} 16 \mathrm{~F} 10$ cell line, $\mathrm{IC}_{50}$ was at $5.264 \mu \mathrm{g} / \mathrm{ml}$. A series of 1,2,4-Triazole derivatives $(\mathrm{C} 2, \mathrm{C} 3)$ were screened for their In -vitro antioxidant properties, through hydrogen peroxide, Nitric oxide, and total antioxidant capacity. The highest activity was indicated during measured $\left(\mathrm{IC}_{50}, \mathrm{TAC}_{50}\right)$ values, with derivatives $\mathrm{C} 2$ and $\mathrm{C} 3$ by comparison with ascorbic acid as standard. Triazole derivative (C3) did not exhibit cytotoxic activity when applied human neuronal glioblastoma tumor (U138 MG) and testes cell line (Tera-1). [DOI: $10.22401 /$ JNUS.21.3.04]
\end{abstract}

Keywords: Cell Viability, Statistical Analysis, Scavenging of Nitric oxide radical, Antioxidant Activity, caspase- 9 activity assay.

\section{Introduction}

Caspase are endo proteases that breakdown amide bonds in an exceedingly reaction that based on chemical action cysteine residues within the caspase site and happens simply when sure aspartic acid residues within the substrate [1,2]. In spite of the very fact that caspase-mediated process will ends up in substrate inactivation, it would likewise produce active signal molecules that participate in ordered procedures [3]. The initiator caspases group includes of (caspase 2,8,9, and 10). The abettor pro-caspases exist as appropriate long pro- domains and monomers, that are activated by dimerization and not by cleavage [4]. From the literature survey it absolutely was found that one, 2,4triazoles and their derivatives have grate importance healthful chemist and may be utilized to assembly diverse "heterocyclic" complexes together totally different biology efficacy like antiviral, anti-bacterial, antifungal, anti-tuberculosis, anticonvulsant drug, antidepressant drug, anti-inflammatory and anticancer efficacy [5]. Restraint of "glycogen synthase kinase3", adversary of "GABA" senses, agonist's of muscarinic pickup, be neuroleptic agent [6], and these compounds additionally show "anti-HIV-1", toxic, antihistamine, also anti-proliferative phase performance [7]. The appearance elevation inspection framework has allowed us to esteem an outsized variety of tiny molecules in parallel and automatic fashions. In response to the present screening innovation, one in every of the best issues in recent drug discovery approach has been steered across a way planning and prepare complex bookstores obtaining in numerous biology protocols [8].

Inspect the effects of triazole synthetic on cell viability of the murine melanoma tumor B16F10, prostate tumor LCCaP, non-small 
cell lung tumor (H1299), neuronal glioblastoma tumor (U138 MG), and testes cell line (Tera-1), and apoptosis mechanism in B16F10 cell cycle phases by caspase- 9 activity technique.

\section{Materials and Methods}

\subsection{Chemistry}

Melting points of the Triazole derivatives were determined using the microcontroller based melting point apparatus. It was recorded using $\mathrm{KBr}$ pellets in FTIR spectrometer (shimadzu 8700). ${ }^{1} \mathrm{H}-\mathrm{NMR}$ (400MHZ) spectra was recorded on a Varian spectrometer in $\mathrm{CDCl}_{3}$ solvent.

\subsubsection{Synthesis of 4-[(3,5-dibromo-4-} methoxybenzenylidene)-amino]-5(pyridine4yl)-4H 1,2,4-triazole-3thiol (C2)

4-amino 5(pyridine-4-yl)-4H1,2,4-triazole3thiol (0.03 mole) with aromatic aldehyde
(0.03) was refluxed in absolute ethanol $(50 \mathrm{ml})$ in a little drops of glacial aceticacid from $4-7$ hrs. The reflection blend was cool down, residue was filtered and recrystallized from ethanol [5].

\subsubsection{Synthesis of 3-(3,5-dibromo-4-} methoxyphenyl)-3(3-mercapto-5(pyridine4yl)-4H 1,2,4- triazol-4yl) thiazolidine 4-one (C3)

A mixture of derivative (C2) (0.06 mole) and "Mercapto Acetic Acid" in (0.09 moles) in dry benzene $(40 \mathrm{ml})$ was refluxed for 14 hours. The blend was intensified and recrystallized by applied ethanol [6].

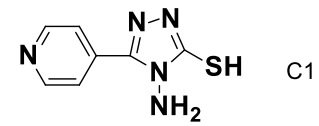

4-amino-5-(pyridin-4-yl)-4H-1,2,4-triazole-3-thiol<smiles>C=Cc1cc(C=O)cc(Br)c1OC</smiles><smiles>COc1c(Br)cc(C=Nn2c(S)nnc2-c2ccncc2)cc1Br</smiles>

4-((3,5-dibromo-4-methoxybenzylidene)amino)-5-(pyridin-4-yl)-4H-1,2,4-triazole-3-thiol

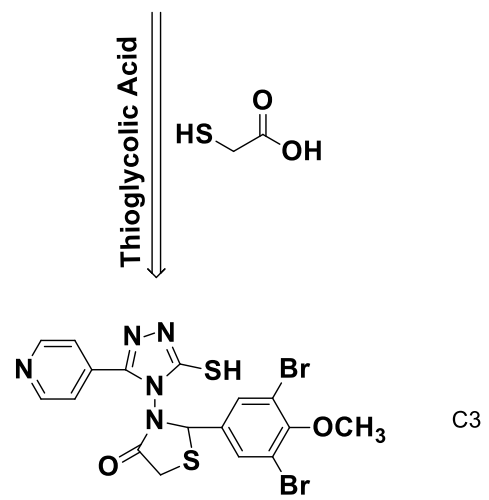

2-(3,5-dibromo-4-methoxyphenyl)-3-(3-mercapto-5-(pyridin-4-yl)-4H-1,2,4-triazol-4-yl)thiazolidin4-one

Fig.(1): Synthetic pathways for the preparation of 2-(3,5-dibromo-4methoxyphenyl)3(3mercapto-5(pyridine-4yl)4H1,2,4-triazol-4-yl)-thiazolidine4-one (C3). 
2.2. In Vitro cytotoxic activity of $1,2,4-$ Triazole derivative $(\mathrm{C3})$

Tumor cells in research inclusive the murine melanoma tumor $\mathrm{B} 16 \mathrm{~F} 10$, prostate tumor LCCaP, non-small cell lung tumor (H1299), neuronal glioblastoma tumor (U138 MG), and testes cell line (Tera-1).

\subsubsection{Cell Viability}

Cytotoxic of tumors (B16F10, LCCaP, H1299, U138 MG, Tera-1) was particular by "MTT" (3-[4,5-dimeathylthiazole-2-yl]-2,5dipheinyl tetraezolium broimide) protocol [9]. "MTT" protocol was instituted on the eclectic capacity living cells to decrease the yellow soluble tetraezolium corn, to a purple blue unsolvable "formazan" sediment. Residues of viability cell were obtained from 3 independent tests for each tumor type. Tumor cells were plated $\left(1 \times 10^{4}\right.$ cells/well $)$ in 96-well plates, these were brooded at $37 \mathrm{C}^{\circ}, 10 \% \mathrm{CO}_{2}$ for 24hr. Next incubation period, agar was extracted and two -folded serial dilution the 1,2,4- Triazole derivative (C3) $(600,300,150$, $75,37.5 \mu \mathrm{g} / \mathrm{ml})$ were added to the plates. Three times were used for each concentration as well as the controls (normal plates). Plates were incubated at $37 \mathrm{C}^{\circ}, 10 \% \mathrm{CO}_{2}$ for selected exposure time, $10 \mu 1$ of the "MTT" solution was added to each well. Agars were carefully removed and $120 \mu \mathrm{l}$ for DMSO solubility solution was added per each well for 10 minutes, determine absorb by an "ELISA" reader at a wavelengths $570 \mathrm{~nm}$.

\subsubsection{Scavenging of Nitric oxide radical}

Scavenging of $\mathrm{NO}$ complete with $\mathrm{O}$ atom leading to decrease production of NO. The reaction mixture $(10 \mathrm{ml})$ containing sodium nitroprusside $(20 \mathrm{mM})$, phosphate buffer saline (PBS, pH 7.2, 2ml) and 1,2,4-Triazole derivatives $(\mathrm{C} 2, \mathrm{C} 3)$ or standard $(2 \mathrm{ml})$ in DMSO at various concentrations was incubated at $25 \mathrm{C}^{0}$ for 140 minutes. Next incubation period, $1.6 \mathrm{ml}$ of the reflection blend containing nitrite ion was extracted, $2 \mathrm{ml}$ of sulpha nilicacid reagent was emphasis added, blended well and pliable to stand 10 minutes for diazotization completion reflection. Then $2 \mathrm{ml}$ of "NEDD" was emphasis added, mixed and pliable to stand at 30 minutes in prevalent light. A pink colored chromophore was created; absorbance was appearing in $540 \mathrm{~nm}$ [10].

\subsubsection{Caspase -Glo 9 luminescent assay kit}

Purified caspase-9 was diluted in $(10 \mathrm{Mm})$ HEPES buffer (PH 7.2) with $0.1 \%$ prionex stabilizer and examine in a total volume of $200 \mu 1$ per well in 96-well plate. Contents the caspase-Glo 9 assay buffer were transferred into the amber bottle containing "caspase-Glo 9 substrate", blend by rounding the contents until the substrate is totally fluxed to shape it. The reagent was allowed to equilibrate to room temperature, mix thoroughly after adding MG/132 inhibitor. These plates containing cells were removed from the incubator, $100 \mu \mathrm{l}$ of caspase- 9 reagent grade was added to each well of a "white-walled 96- well plate" containing $100 \mu \mathrm{l}$ of gab, these plate were wrapped with a plate sealer. Contents well were blended softly using a plate shaker instrument about (300 rpm) for 35 seconds and incubated for 35 minutes. The luminescence was measured of each derivative in a plate/reading luminometer instrument [11].

\subsection{Statistical Analysis Measurement}

A one-way dissection of distinction ANOVA "Duncan" was completed to experience whether group distinction was considerable $(p<0.01)$ or not. The statistical analysis measurement "system- SAS" (2012) platform was utilized to study the difference factors in study parameters. Least significant difference-LSD experience was utilized for considerable compared among intermediary in this research [12].

\section{Results and Discussion}

\subsection{Chemistry}

FTIR (KBr, cm-1) for compound (C1): stretching bands of $\mathrm{NH} 2$ symmetric and asymmetrical at $(3470,3310), \mathrm{SH}$ band at (2580). Bands at (3120.6) for $(\mathrm{NH})$, bands of $(\mathrm{C}=\mathrm{N})$ and $(\mathrm{C}=\mathrm{C})$ aromatic appear at $(1650.5)$ and (1540), respectively. 1H-NMR (CDCI3) $\sigma(\mathrm{ppm})$ : shows a singles at (7.231- 7.644) due to phenyl, single indicative at (6.562) for $\mathrm{NH} 2$, single indicative at 14.372 for $(\mathrm{S}-\mathrm{H})$ band.

FTIR (KBr, cm-1) for derivative (C2):disappearance of $\mathrm{NH} 2$ band and appearance of absorption bands at (16101627) for the imine $(\mathrm{C}=\mathrm{N})$ as evidence for 
formation of derivative (C2). 1H-NMR (CDCI3) $\sigma(\mathrm{ppm})$ :appearance of singlet signal at $9.853 \mathrm{ppm}$ for azomethine- group $(\mathrm{C}=\mathrm{N})$, double signal at 8.3-8.8 for two hydrogen in pyridine ring, singlet signal at 12.951 for $\mathrm{S}-\mathrm{H}$ bond.

FTIR (KBr, cm-1) for derivative (C3): disappearance of $(\mathrm{C}=\mathrm{N})$ band and appearance of the carbonyl band due to thiazolidinone ring at (1725- 1733) and the (C-S-C) band at (650$690 \mathrm{~cm}-1)$. 1H-NMR (CDCI3) $\sigma$ (ppm): single indicative at 3.24 due to methylene group (COCH2S), single indicative at 5.629 for $\mathrm{CH}(\mathrm{SCHN})$, double indicative of two hydrogen in pyridine ring at (7.9- 8.4), triple signal for three hydrogen in methoxy group at 3.3, singlet signal at 13.785 for $(\mathrm{S}-\mathrm{H})$ group.

\subsection{Cell Viability Measurement}

From the results of (Table 1) it was found that 1,2,4-Triazole derivative (C3) having methylene group $(\mathrm{COCH} 2 \mathrm{~S})$ with $\mathrm{CH}(\mathrm{SCHN})$ (Thiazoliedinone ring) displayed arise efficiency versus B16F10 cell line and LCCaP cell line together $\mathrm{IC}_{50}$ values $(41 \mu \mathrm{g} / \mathrm{ml}$ and $54.11 \mu \mathrm{g} / \mathrm{ml}$ ) than the normal cell with $\mathrm{IC}_{50}$ values $(159.6 \mu \mathrm{g} / \mathrm{ml}$ and $150.5 \mu \mathrm{g} / \mathrm{ml})$. Also, it was found that derivative (C3) exhibited a remarkable activity against $\mathrm{H} 1299$ cell line with $\mathrm{IC}_{50}$ value $(109.9 \mu \mathrm{g} / \mathrm{ml})$ in significant difference at P-value (0.005) [8]. In addition, compound $(\mathrm{C} 3)$ revealed no activity against U138 MG cell line and Tera- 1 cell line, that no significant difference in $\mathrm{P}$-value 0.650 .

Table (1)

Cytotoxic effects of 1,2,4-Triazole derivative (C3) to different tumor cell lines for 24 hour.

\begin{tabular}{||c||c|c||c||}
\hline \multirow{2}{*}{ Cell Lines } & $\begin{array}{c}\text { Triazole } \\
\mathbf{( C 3 )} \\
\boldsymbol{\mu g} / \mathbf{m l}\end{array}$ & $\begin{array}{c}\text { Normal } \\
\text { Cells } \\
\mathbf{\mu g} / \mathbf{m l}\end{array}$ & \multirow{2}{*}{ P-value } \\
\cline { 2 - 3 } & $\mathbf{I C}_{\mathbf{5 0}}$ & $\mathbf{I C}_{\mathbf{5 0}}$ & \\
\hline \hline B16F10 & $41 \pm 2.2$ & $159.6 \pm 8$ & $<0.0001$ \\
\hline \hline LCCaP & $54.11 \pm 1.4$ & $150.5 \pm 0.7$ & $<0.0001$ \\
\hline \hline H1299 & $109.9 \pm 0.8$ & $205 \pm 0.51$ & 0.005 \\
\hline \hline U138 MG & $150.2 \pm 2.6$ & $172.6 \pm 2.9$ & 0.650 \\
\hline \hline Tera-1 & $125.4 \pm 3.2$ & $149.7 \pm 4.6$ & 0.650 \\
\hline
\end{tabular}

1,2,4-Triazole derivative (C3) was estimated for their in-vitro toxic efficiency in respect diverse of cell lines after 24 hour of nursery using the criterion "MTT" protocol. According to the $\mathrm{IC}_{50}$ results show in Fig.(2),
Triazole derivative (C3) was obviously high powerful in the tumor plates and, thus, was used in moreover in-vitro researches. For murine melanoma cell lines (B16F10), derivative $(\mathrm{C} 3)$ pretend have a minimize $\mathrm{IC}_{50}$, however, this result was statistically considerable at $(\mathrm{P}<0.0001)$ by comparison with normal cells. Triazole derivative (C3) did not revelation cytotoxic efficiency when utilized human neuronal glioblastoma tumor (U138 MG) and testes cell line (Tera-1) [13], as shown in Fig.(3).
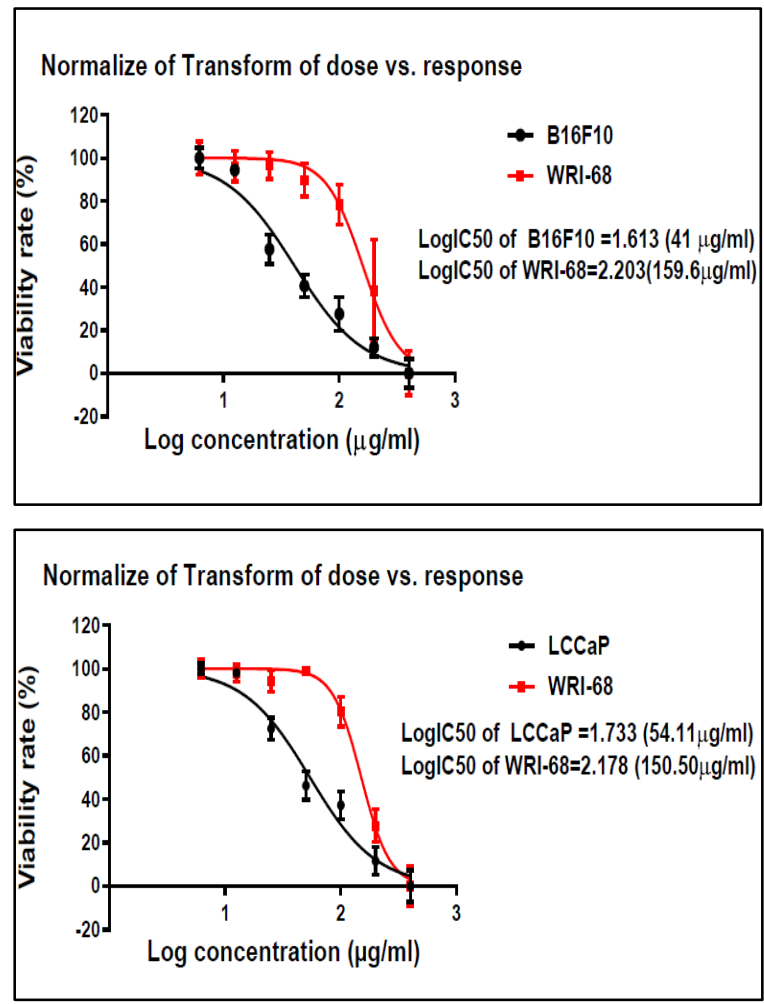

Normalize of Transform of dose vs, response

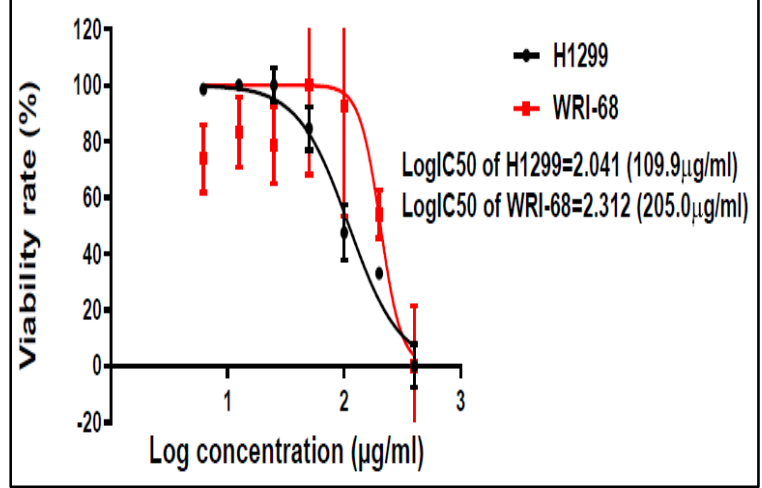

Fig.(2): Effect of 1,2,4-Triazole derivative (C3) on murine melanoma tumor (B16F10), prostate cancer tumor (LCCaP), and nonsmall cell lung tumor (H1299), represent by significantly different in P-value $<0.0001$, $0.0001,0.005$, respectively. 

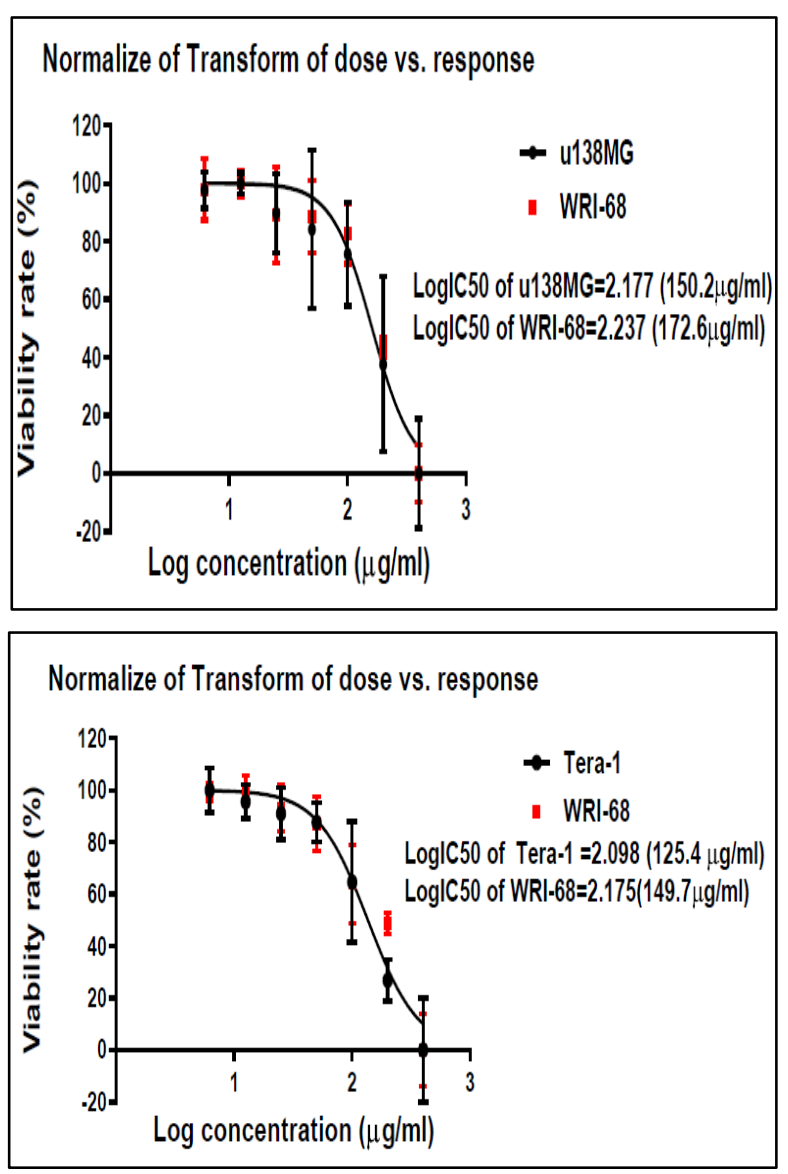

Fig.(3): Effect of 1,2,4-Triazole derivative (C3) human neuronal glioblastoma cell line (U138 MG), and testes cell line (Tera-1), represent by No significantly different in $P$ value $(0.650,0.294)$, respectively.
The pictures for "B16F10" tumor that have been treated together 1,2,4 triazole derivative (C3) as a positive control, and culture media (Normal cell)as a negative control, for 24 hour. The cells were spotted with "Hoechst 33342 dye" (excitation 330/emission 420) which enables observation of cell loss, cell membrane permeability dye (excitation 491/emission 509), "MMP dye" (excitation552/emission 576) for mitochondrial membrane potential changes, and goat anti-mouse secondary antibody conjugated with DyLight "TM 649" for cytochrome c emission. 1,2,4 triazole derivative (C3) spotted "B16F10" tumor and the spotted effect was not similar as for normal cell, as are shown in Fig.(4) below.

\section{Nucleus Permeability dye}

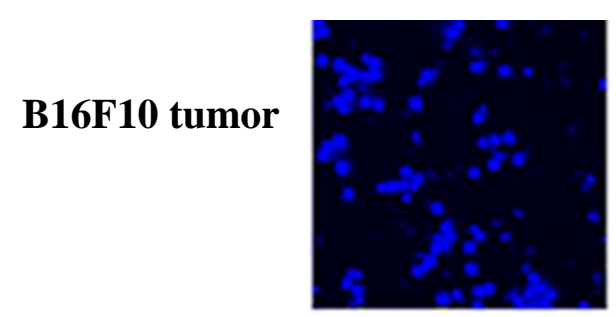

Normal cell
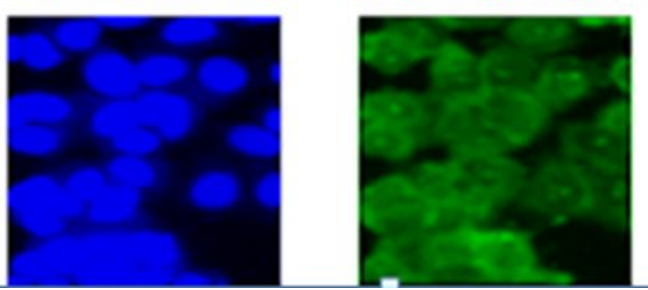

MMP
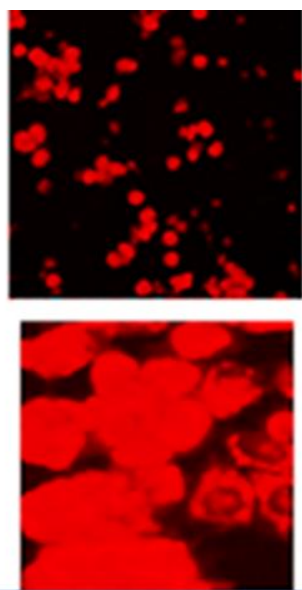

Cytochrome
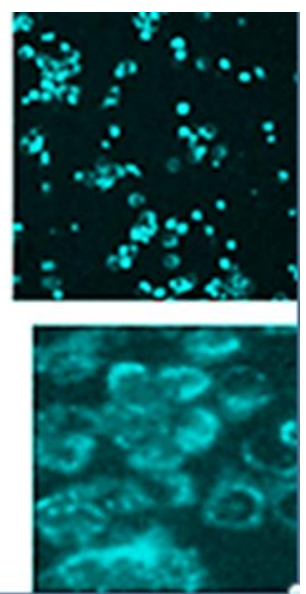

Fig.(4): Toxic parameters (Nucleus, permeability dye, mitochondrial membrane permeability, cytochrome) for murine melanoma tumor "B16F10", comparison with normal cell by application high content screening technique (HCS).

\subsection{Antioxidant Activity}

Derivative (C3) possessed potent inhibitory activity against hydrogen peroxide and total antioxidant capacity. A lower $\mathrm{TAC}_{50}$ and $\mathrm{IC}_{50}$ values indicates greater antioxidant activity with TAC value $784 \mu \mathrm{g} / \mathrm{ml}$ and TAC50 value $18.57 \mu \mathrm{g} / \mathrm{ml}$, as shown in Table (2). 
Table (2)

hydrogen peroxide and total antioxidant capacity of derivative (C3) in vitro.

\begin{tabular}{|c||c|c||c||c||}
\hline \multirow{2}{*}{ Derivative No. } & \multicolumn{2}{|c||}{ IC $_{\mathbf{5 0}} \pm$ SD $(\boldsymbol{\mu g} / \mathbf{m l})$} & \multirow{2}{*}{ TAC } & \multirow{2}{*}{ TAC $_{\mathbf{5 0}}$} \\
\cline { 2 - 3 } & Hydrogen peroxide & Nitric oxide & & \\
\hline \hline C2 & $44 \pm 0.38$ & $46 \pm 0.01$ & $782.2 \pm 0.48$ & $18.57 \pm 0.36$ \\
\hline C3 & $40 \pm 0.03$ & $39 \pm 0.06$ & $424 \pm 0.22$ & $38.93 \pm 012$ \\
\hline Ascorbic Acid & $58 \pm 0.46$ & $55 \pm 0.08$ & - & - \\
\hline
\end{tabular}

\subsection{In vitro caspase- 9 activity assay}

Caspase- 9 is effectiveness caspase and belongs to intrinsic apoptosis activation pathways [14]. The results of caspase-9 activity reveal that there is a significant increase in mean activity which was (16822, 108284) in B16F10 cells treated with 600 $\mu \mathrm{g} / \mathrm{ml}$ and $150 \mu \mathrm{g} / \mathrm{ml}$ of $1,2,4-$ Triazole derivative (C3), respectively, at $\mathrm{IC}_{50}(5.264$ $\mu \mathrm{g} / \mathrm{ml}$ ), as shown in Table (3). The caspase-9 activity technique are directly correlated to the toxic effect of derivative (C3) tested because it at these concentrations has an influence on cell membranes correlating with rapid variation in membrane permeability, which leads to reduced viability and cells death [15].

Table (3)

1,2,4-Triazole derivative (C3) effect of caspase-9 activity in murine melanoma cell line (B16F10) after incubation for 24 hours at $37 C^{\circ}$.

\begin{tabular}{|c||c|}
\hline $\begin{array}{c}\text { Derivative }(\mathbf{C 3}) \\
\text { concertation }(\boldsymbol{\mu g} / \mathbf{m l})\end{array}$ & $\begin{array}{c}\text { Caspase } \\
(\text { Mean } \pm \text { SD) }\end{array}$ \\
\hline \hline 600 & $16822 \pm 6252^{\mathbf{c}}$ \\
\hline \hline 150 & $108284 \pm 3450^{\mathbf{c}}$ \\
\hline 75 & $33741 \pm 2960^{\mathbf{a}}$ \\
\hline \hline 37.5 & $22564 \pm 2110^{\mathbf{b}}$ \\
\hline \hline $0 \mu \mathrm{g} / \mathrm{ml}$ DMSO & $4612 \pm 843.2^{\mathrm{d}}$ \\
\hline \hline $\mathrm{LSD}$ value & 1180 \\
\hline
\end{tabular}

Letters ${ }^{a, b, c, d}$ refers to significant result at $\mathrm{P}<0.05$ LSD $=$ Least significant Difference

\section{Conclusion}

1,2,4-Triazole derivative (C3) was synthesized and this in vitro antitumor cytotoxic activity was evaluated on five tumor cell lines, which showed higher activity in B16F10 cell line. Derivatives (C2 and C3) can or may be used as easily accessible source of antioxidant and tumor treatment. Cytotoxic effect of 1,2,4-Triazole derivative (C3) has been demonstrated on $\mathrm{B} 16 \mathrm{~F} 10$ cell line by using caspase- 9 activity assay at $\mathrm{IC}_{50}$ concentration measured.

\section{Acknowledgements}

The author would like to thank Dr.Ahmed Al-Neama, Biotechnology research center in Al-Nahrain university, for providing all the research facilities and Ms.Hazrina Hazni (Malaya University) for measuring NMR.

\section{References}

[1] Taylor R., Cullen S., Martin S., Apoptosis controlled demolition at the cellular level, J. Nat. Rev. Mol. Cell. Biol., 9, 231-241, 2008.

[2] Wurstle M., Laussmann M., Rehm M., The central role of initiator caspase- 9 in apoptosis signal transduction and the regulation of its activation and activity on the apoptosis, Expert. Cell. Res., 318(11), 1213-1220, 2012.

[3] Rongvaux A., Jackson R., Harman C., Li T.,West A., De Zoete M., Wu Y., Yordy B., Lakhani S., Kuan C., and Taniguchi T., Apoptotic caspase prevent the induction of type I interferons by mitochondrial DNA, J. Cell., 159(7), 1563-1577, 2014.

[4] Indran R., Tufo G., Pervaiz S., Brenner C., Recent advances in apoptosis mitochondria and drug resistance in cancer cells, J. Biochem. Biophys. Acta., 1807, 735-745, 2011.

[5] Xiang L., Xue L., He-Mei L., Xue-Zhang Z., Zhi-Hui S., Synthesis and evaluation of antitumor activities of novel chiral 1,2,4triazole Schiff bases bearing y-butenolide moiety, J. Org. Med. Chem. Lett., 2(26), 1897-1915, 2012.

[6] Bhat S., Poojary D., Prasad P., Naik S., Synthesis and antitumor activity studies of some new fused 1,2,4-triazole derivatives 
carrying 2,4-dichlorofluorophenylmoiety, Eur. J. Med. Chem., 44, 5066-5070, 2009.

[7] Bayrak H., Demirbas S., Karaoglu N., Demirbas S., Synthesis of some new 1,2,4triazoles, their Mannich and Schiff bases and evaluation of their antimicrobial activities, Eur. Med. Chem., 44, 10571066, 2009.

[8] Hassan F., Ahmed A., Alaa J., Antitumor effect of 1-[(4-chloro-benzylidine)-amino]5-phenyl-1H-pyrrole-2-Thiol in different type of cell lines, J. Austral. Appl. sci., 9(35), 44-48, 2015.

[9] Leila F., Ronald M., Elena T., Katherine S., Frederick D., Alexander T., Comparison of cytotoxic activity of anticancer drugs against various human tumor cell lines using in vitro cell-based approach, Int. J. Biomed. Sci., 8(1), 76-80, 2012.

[10] Brune B., Nitric oxide: NO apoptosis or turning it NO., cell death and differentiation, 10(8), 864-869, 2003.

[11] Chung L., Aditya A., Foo C., Bushr M., Kok L., Khalit M., Won W., Nitika K., Mohad M., Introduction of apoptosis in human breast cancer cells via caspase pathways by vernodalin isolated from centratherum anthelminticum (L.) seeds, J, Pluse one, 8(2), 1-19, 2013.

[12] SAS, Statistical analysis system, users Guide. statistical version 9.1 th ed. SAS. Inst. Inc. Cary. N. C. USA, 2012.

[13] Hassan F., Hameed A., Ahmed A., Bashar A., Hasniza H., Nany H., Yousif E., Atitumor activity for Gold (III) complex by high content screening technique (HCS) and cell viability assay, Asian J. Biochem., 10(6), 252-266, 2015.

[14] Galluzzi L., Senovilla L., Zitvogel L., Kroemer G., The secret ally: immunostimulation by anticancer drugs, J. Nat. Rev. Cancer, 11, 215-233, 2012.

[15] Hassan F., El-Hiti G., Mays A., Yousif E., Cytotoxicity anticancer activities of anastrozole against breast, liver hepatocellular, and prostate cancer cells, J. Saudi Med., 38(4), 359-365, 2017. 